\title{
Sociobiology
}

RESEARCH ARTICLE - ANTS

\section{Survey of Ants in Dry Forests of Southwestern Ecuador (Hymenoptera: Formicidae)}

\author{
JE LATTKE ${ }^{1}$, M VÉLEZ $^{2}$, N AgUIRRE ${ }^{2}$ \\ 1 - Universidade Federal do Paraná, Curitiba-PR, Brazil \\ 2 - Universidad Nacional de Loja, Loja, Ecuador
}

\section{Article History}

\section{Edited by}

Evandro Nascimento Silva, UEFS, Brazil

Received

Initial acceptance

Final acceptance 18 April 2016

07 August 2016

24 August 2016

25 October 2016

\section{Keywords}

Tumbesian forests, biodiversity, new records, endemism.

\section{Corresponding author}

John E. Lattke

Departamento de Zoologia,

Universidade Federal do Paraná

Caixa Postal 19020, CEP 81531-980

Curitiba-PR, Brasil

E-Mail: piquihuye@gmail.com

\begin{abstract}
Two dry forests of southwestern Ecuador separated $43 \mathrm{~km}$ from each other, one situated at $460 \mathrm{~m}$ above sea level and the other at $680 \mathrm{~m}$, are surveyed for ants giving a total of 28 species collected manually and from pitfall traps. Eleven species are shared between the sites whilst four are exclusive to one site and 13 to the other. Differences in humidity, rainfall seasonality, and disturbance regimes may account for at least part of the differences observed between the ant communities of the two sites. Dorymyrmex pyramicus peruvianum Wheeler, 1919 and Pseudomyrmex kuenckeli (Emery, 1890) are reported from Ecuador for the first time. Cardiocondyla emeryi Forel, 1881 and Camponotus conspicuus zonatus Emery, 1894 are reported from mainland Ecuador for the first time. The genus Dorymyrmex Mayr, 1866 is recorded from Ecuador for the first time.
\end{abstract}

\section{Introduction}

The status of Ecuador as hyperdiverse in terms of its biological heritage is well documented, but the coverage for studies supporting this reality is uneven as most studies are concentrated on the northeastern Amazon region or the Galapagos Islands. Considerable parts of the country have barely been sampled (Guayasamin \& Bonaccorso, 2011) or remain unknown (Brehm et al., 2008). The seasonally dry forests of southwestern Ecuador are such an area, extending into Peru and forming the Tumbesian region with an extension of over 130,000 $\mathrm{km}^{2}$ (Loaiza, 2013), they are considered the least well characterized of the seasonally dry forests in the American Tropics (Särkinen et al., 2011). The dry forests on the Ecuadorean side are considered better preserved than in Peru, yet at least $50 \%$ of the original cover has been lost (Aguirre-Mendoza \& Kvist, 2005). The dry forests on the Ecuadorean side were declared part of the World Network of Biosphere Reserves by the UNESCO in 2014. What little is known of them points to important endemism for plants and birds (Linares-Palomino et al., 2010). Studies of insects in the seasonally dry forests of Southern Ecuador are scarce and more recent (Domínguez et al., 2015), and for ants in particular, nonexistent (Salazar et al., 2015).

Ants are an ecologically dominant and diverse group of insects that intervene in important processes for the maintenance of many ecosystems, particularly in the tropics (Folgarait, 1998; Del Toro et al., 2012; Guenard, 2013). They are sensitive to environmental change and easily sampled quantitatively, winning them an established role as biological indicators (Underwood \& Fisher, 2006; Majer et al., 2007, Ribas et al., 2012). These and other traits have made for an ever increasing amount of studies on their diversity and the roles they play in ecosystems. Given the increasing amount of interdisciplinary research in southern Ecuador centering around conservation, biodiversity, and climate change (Gradstein et al., 2008; Bendix et al., 2013), the lack of knowledge about a key group of organisms, such as the region's ants, is a major 
hindrance towards greater understanding of the regional patterns and processes of biological diversity. An exploratory survey using both quantitative and qualitative collecting methods was undertaken to collect and identify at least the most common ants in the study area and establish a baseline of ant diversity information for steering further studies. The first results of this work are presented.

\section{Materials and methods}

Study sites

Sampling was carried out during the last days of September and first week of October of 2014 during the dry season in two dry forests of southwestern Ecuador. Both sites are located in Loja Province.

Site I. Zapotillo Canton. Hacienda El Chilco, 14 km NNW of Zapotillo, $-04.26306^{\circ},-80.26874^{\circ}, 460 \mathrm{~m}$. The site is owned and managed by the Universidad Nacional de Loja as a place for field studies. The terrain is rolling hills with a sparse forest and shallow leaf litter layer where Ceiba trichistandra Bakh., Eriotheca ruizii (K. Schum.) A. Robyns, and Tabebuia chrysantha (Jacq.) G. Nicholson are amongst the dominant species (Muñoz et al., 2014). The Hacienda is regularly entered by herds of goats from neighboring lands where they browse at leisure. Average annual precipitation between the years 2000 and 2010 in Zapotillo was recorded as $884 \mathrm{~mm}$, ranging from $243 \mathrm{~mm}$ in 2003 to $1506 \mathrm{~mm}$ in 2008. Most rainfall is concentrated from January to April, and the remaining months are considered the dry season; temperatures averaged $25.6^{\circ} \mathrm{C}$ annually and relative humidity $75.2 \%$ during the same period (INAMHI, 2000-2010).

Site II. Macará Canton. Reserva Laipuna, $20 \mathrm{~km}$ NNE Macará, $-04.21056^{\circ},-79.88682^{\circ}, 680 \mathrm{~m}$. The site is owned and managed by Naturaleza y Conservacion Internacional, an NGO based in Loja, Ecuador and is part of a regional system of sites for long-term environmental monitoring (Bendix et al., 2014). The reserve is on steep slopes facing the Catamayo River. Sierra et al. (1999) classifies the general area as a montane thorny scrub forest (espinar seco montano). The sampling site lacks significant leaf litter and, besides the presence of shrubs and trees, also had columnar cactus (not present in El Chilco). Published information dealing with the biota of the site is scarce, and apparently lacking in refereed journals. One unpublished thesis from a local university (Ambuludí, in thesis) cites some of the dominant trees as Eriotheca ruizii (K. Schum.) A. Robyns, Acacia macracantha Humb. \& Bonpl. ex Willd., and Bursera graveolens (Kunth) Triana \& Planch. Precipitation between 2008 and 2009 averaged $617 \mathrm{~mm}$ annually, with most of it concentrated from January to March (Peters \& Richter, 2011), implying very marked seasonality. For the same period the average annual temperature was $23.3^{\circ} \mathrm{C}$ and average annual relative humidity was $78 \%$. The Laipuna site is $42.7 \mathrm{~km}$ WSW from El Chilco. The soil proved quite hard in both sites, necessitating the use of metallic chisels and a hammer to permit placement of pitfall traps.
Data Collection

Field activities: Ants for quantitative analysis were collected using a modified ALL protocol (Bestelmeyer et al., 2000) whilst complementary data on ant diversity was obtained by manual collecting. The modification to the original ALL protocol was imposed by logistical constraints that imposed reducing the running time of the pitfall traps to 24 hours (instead of the standard 48 hours) before being gathered and emptied of their contents. Leaf litter samples and pitfall traps were used in El Chilco, but only pitfall traps were used in Laipuna as the ground is mostly bare with scant, small fallen leaves, and a few dry branches scattered upon the surface. A linear transect of $220 \mathrm{~m}$ was set up at El Chilco and 20 one $\mathrm{m}^{2}$ plots, separated $10 \mathrm{~m}$ from each other, were delimited. The litter was collected from each plot and sifted with a Winkler sieve; the material was placed in cloth bags, one for each sample. Strictly leaf litter was collected as the hard ground did not permit the scraping of topsoil or nonexistent humus. Litter was sampled at mid-morning under the thin shade of the canopy and processed with mini-Winkler extractors during 48 hours, with removal and refilling of the litter from each extractor at 24 h (Guénard \& Lucky, 2011). Pitfall traps were placed parallel to the litter transect, one pitfall $10 \mathrm{~m}$ distant from each plot. Each pitfall trap consisted of a 10 ounce disposable plastic cup placed at the same level as the surrounding ground filled one-third to one-half with a solution of water and a drop of liquid dishwashing soap to break the surface tension. The pitfall traps were left running during 24 hours before being gathered and emptied of their contents. Additional ants were collected manually at each site during 1.5 - 2 hours by five persons during two days. Ants were manually collected at night until 23:00 $\mathrm{h}$ in the Laipuna site. Field activities were covered by permit 011-2014-IC-FLO-DPLMA granted by the Ecuadorean Ministry of the Environment.

Lab activities: Ants were kept in vials with $90 \%$ ethanol. Ants from each sample were put in petri dishes and sorted into morphospecies using a Zeiss Stemi 2000$\mathrm{C}$ stereo microscope. In the case of genera with numerous species, a fiche was kept for each species with sketches and diagnostic characters highlighted and defined. Relevant taxonomic literature was consulted for species identifications as well as online resources such as Antweb (2016a), and Antwiki (2016a). For comparative purposes specimens from the Ecuadorian Ant Reference Collection (ARC-E), housed in the Instituto de Ciencias Biológicas of the Escuela Politécnica Nacional in Quito and curated by Dr. David Donoso, were also consulted. Ants identified to morphospecies bear an ARC-E morphospecies number (EC-\#\#). ARC-E serves as a national reference collection for all ant species of Ecuador. Only worker ants were considered for the quantitative analysis as solitary queens or males do not necessarily imply an established colony. Solitary soldier ants, not associated with the worker caste, were also excluded from the analysis so as not to inflate the species number by misidentifying as 
different species, different castes of the same species, a hazard especially relevant for Pheidole. Solenopsis is a particularly rich genus in southern Ecuador and there are indications that using morphology alone in determining species for the smaller "thief ants" group of this genus can be extremely misleading (Delsinne et al., 2012). Given such a degree of uncertainty, thief ants were excluded from the present study, nevertheless apparent morphospecies were mounted in repeated series. Solenopsis species of the geminata group (Trager, 1991) were included for the analysis. Voucher specimens of all species and morphospecies (including thief ants) have been deposited in the ARC-E collection. Specimens of rare species and type specimens of new species to be described will be deposited in the Quito Catholic Zoology Museum, QCAZ, Pontificia Universidad Católica de Ecuador. Additional material is deposited in the insect collection of the Universidad Nacional de Loja, Loja, Ecuador. Specimens collected in Zapotillo cover Lattke collection numbers from 3598 to 3604 with 36041 to 3604-20 covering the pitfall trap transect. Specimens collected in Macará cover Lattke collection numbers from 3605 to 3617 with $3611-1$ to $3611-20$ covering the pitfall transect. Additional specimens were collected in both sites by M. Vélez and three field assistants. Towards the end of this project we were given the opportunity to have DNA extracted from some of the specimens for barcoding by the International Barcode of Life Consortium. The data may be accessed at the following URL: http://dx.doi.org/10.5883/DS-DRYLOJA. These results will be treated in a separate publication covering the barcoding of ants in additional dry forest sites in southern Ecuador (Domínguez et al., 2016).

\section{Data Analysis}

Litter and pitfall data was organized as presence abscence (incidence) of each morphospecies for each sample plot as ants are colonial organisms. Mao Tao species accumulation curves were calculated using Estimates 9.1.0 (Colwell, 2013). Using the same software the following estimators were calculated after 100 random shufflings of the samples: ICE, Chao 2, and Second Order Jackknife (JK2). Beta diversity comparison uses the Chao Jaccard Index, also calculated by Estimates 9.1.0. The present functional groups (FGs) are conceptually based upon Silvestre et al. (2003), Anderson (2010), and Narenda et al. (2010) but modified taking into account known natural history and phylogenetic affinities: (1) - Generalist epigeic hunters. Predatory ants of medium to small size (body length 0.8 to $1.5 \mathrm{~cm}$ ) that forage and hunt on the ground and leaf-litter. (Examples: smaller species of Odontomachus Latreille and Ectatomma Smith). (2) - Nomadic hunters. Ants that hunt as a group with temporary nests, all of the Dorylinae. (3) - Fungus growing ants (detritus). Attines that do not cut foliage for making their fungus gardens, but use miscellaneous organic matter instead (Cyphomyrmex Mayr). (4) - Fungus growing (foliage) ants that preferably gather fresh leaves (Acromyrmex Mayr).
(5) - Epigeic omnivores. Large to medium-sized ants that forage upon the ground and litter surface. (Camponotus Mayr, Dorymyrmex Mayr, Solenopsis geminata (Fabricius 1804), Pheidole Westwood, and some Pseudomyrmex Lund). (6) Arboreal foragers. Ants that nest and mainly forage in trees, shrubs, cacti, and epiphytes (Cephalotes Latreille, Azteca Forel, most Pseudomyrmex). Dissimilarity of species between functional groups $(\mathrm{FG})$ was quantified by the Complementarity Index: $\mathrm{C} a b=\mathrm{U} a b / \mathrm{S} a b$, where $a$ is the number of species in FG A, $b$ the number of species in FG $\mathrm{B}$, and $c$ is the number of shared species between A and B. Uab is the number of species unique to any of the two FGs, $a+b-2 c$, and $\mathrm{S} a b$ is the total richness from both $\mathrm{FG}, a+b-c$ (Colwell and Coddington 1994). If all species are different for each FG the value is one and it is zero if all are the same.

\section{Results}

\section{Richness and abundance}

A total of 17 genera and 28 species from seven subfamilies were found (Table 1). The richest subfamily is Myrmicinae with 12 species from eight genera and the poorest are Ectatomminae and Ponerinae, both with only one species. The most species rich genera are Pheidole, with five species, and Camponotus, with four species. Twelve genera have only a single species. Apparently one Solenopsis Westwood thief ant species was found in El Chilco and perhaps two to three in Laipuna, the Chilco species is apparently also present in Laipuna. El Chilco has a total of 16 species and nine genera from six subfamilies. Ten of these species were sampled with pitfall traps whilst none were recovered from leaf-litter samples. Two of the pitfall traps failed to capture any ants while the rest had from one to four species with an average of 1.6 species per trap for the whole transect. The most species rich subfamily is Myrmicinae with five species, followed by Formicinae with three species. Laipuna has a total of 25 species and 15 genera from seven subfamilies. Eleven of these species were sampled with pitfall traps. All pitfall traps had at least one species present, with an average of two and a maximum of five species per trap. The most species rich subfamily is Myrmicinae with at least 12 species, followed by Dolichoderinae, Formicinae, and Pseudomyrmicinae with four species each (Table 1).

The species accumulation curves for both sites are similar, climbing gently with nine species attained for the tenth sample in Laipuna (Fig 2) and eight for El Chilco (Fig 3 ), the Laipuna curve showing more flattening towards the end. In contrast, the estimators show different behaviors between the two sites. Estimators for Laipuna converge upon the observed species curve with a difference of $86-98 \%$ from the sampled value, suggesting the presence of 12 species. Estimators for El Chilco are spread out, with differences of 72$91 \%$ suggesting the presence of up to 14 species (Table 2). In both sites manual sampling proved more effective in terms of 
Table 1. Species collected at each locality. Functional group abbreviations: Arboreal $=$ nest and forage in plants, Fung D = Fungus grower using detritus as substrate, Fung L = Fungus grower using fresh leaves as substrate, Gen $\mathrm{H}=$ Generalist Hunter, Epi Om = Epigeic omnivore, Nom $\mathrm{H}=$ Nomadic hunter. See more detailed explanation in text. $\mathrm{N}=$ total number of pitfall traps in which species is present. Under "Freq" whole numbers equal to number of pitfall traps where each species was recorded at each site and between parenthesis is the relative frequency of the species at each site according to pitfall samples only. PF = Pitfall Traps. Manual= Manual collection.

\begin{tabular}{|c|c|c|c|c|c|c|}
\hline \multirow[t]{2}{*}{ Taxa } & \multirow[t]{2}{*}{ Functional Group } & \multirow[b]{2}{*}{$\mathbf{N}$} & \multicolumn{2}{|r|}{ Chilco 460m } & \multicolumn{2}{|c|}{ Laipuna $680 \mathrm{~m}$} \\
\hline & & & Freq & Sampling method & Freq & Sampling method \\
\hline \multicolumn{7}{|l|}{ DOLICHODERINAE } \\
\hline Azteca $\mathrm{EC}-04$ & Arboreal & 2 & $2(0.10)$ & $\mathrm{PF}$, manual & & manual \\
\hline Dorymyrmex pyramicus peruvianum & Epi Om & & & & & manual \\
\hline \multicolumn{7}{|l|}{ DORYLINAE } \\
\hline Labidus coecus & Nom $\mathrm{H}$ & & & & & manual \\
\hline Neivamyrmex iridescens Borgmeier, 1950 & Nom $\mathrm{H}$ & & & manual & & \\
\hline \multicolumn{7}{|l|}{ ECTATOMMINAE } \\
\hline Ectatomma ruidum & Gen $\mathrm{H}$ & 2 & & & $2(1.0)$ & PF, manual \\
\hline Camponotus EC-07 (cf. conspicuus zonatus) & Epi Om & & & & $1(0.05)$ & PF, manual \\
\hline Camponotus EC-08 & Epi Om & 5 & $4(2.0)$ & PF, manual & $1(0.05)$ & PF, manual \\
\hline \multicolumn{7}{|l|}{ MYRMICINAE } \\
\hline Acromyrmex EC-02 (octospinosus gp.) & Fung L & 5 & $2(0.10)$ & PF, manual & $3(1.5)$ & PF, manual \\
\hline Cardiocondyla emeryi & Epi Om & & & & & manual \\
\hline Cephalotes maculatus & Arboreal & & & & & manual \\
\hline Crematogaster EC-06 (crinosa complex) & Arboreal & 3 & & manual & $3(1.5)$ & PF, manual \\
\hline Cyphomyrmex EC-06 (rimosus complex) & Fung D & & & & & manual \\
\hline Solenopsis geminata & Epi Om & 2 & & & $2(1.0)$ & PF, manual \\
\hline Solenopsis ssp. & & & & & & $2 \mathrm{ssp}$ \\
\hline \multicolumn{7}{|l|}{ PONERINAE } \\
\hline Odontomachus bauri & Gen $\mathrm{H}$ & 14 & $7(3.5)$ & PF, manual & $7(3.5)$ & PF, manual \\
\hline \multicolumn{7}{|l|}{ PSEUDOMYRMECINAE } \\
\hline Pseudomyrmex boopis & Epi Om & 1 & $1(0.05)$ & $\mathrm{PF}$, manual & & \\
\hline Pseudomyrmex gracilis & Arboreal & & & & & manual \\
\hline Pseudomyrmex kuenckeli & Arboreal & & & & & manual \\
\hline Pseudomyrmex EC-03 & Arboreal & & & & & manual \\
\hline Total species & & & & 15 & & 24 \\
\hline
\end{tabular}

the number of collected species, with 24 species collected in Laipuna and 11 in El Chilco. This compares with 11 and nine species respectively for each site just using pitfall tramps. Of 28 species only Camponotus conspicuus zonatus (Emery, 1894) and Rogeria EC-06 were taken exclusively by pitfall traps.
Beta diversity

Of the 28 species collected, 11 species are shared between the two sites with four exclusive to El Chilco and 13 exclusive to Laipuna (Figure 1, Table 3). Considering only 
Table 2. Pitfall trap alpha diversity for sampled sites. 1 - total species collected in each transect, 2 - species collected only in that transect, 3 species collected in only one quadrat ( 0.05$)$ and their proportion relative the total number of species for the transect, 4 - species collected in two quadrats $(0.10)$ and their proportion relative the total number of species for the transect. Species richness according to the following estimators: 5 - ICE, 6 - Chao 2, 7 - Jackknife 2; 8 - minimum and maximum values of the proportion of observed species according to the estimators.

\begin{tabular}{ccccccccc}
\hline Samples & Collected $^{1}$ & Exclusives $^{2}$ & Uniques $^{\mathbf{3}}$ & Duplicates $^{4}$ & ICE $^{\mathbf{5}}$ & Chao 2 $^{\mathbf{6}}$ & JK2 $^{\mathbf{7}}$ & \% range $^{\mathbf{2}}$ \\
\hline Chilco & 10 & $3(30 \%)$ & $3(30 \%)$ & $2(20 \%)$ & 12.21 & 10.95 & 13.84 & $72-91 \%$ \\
Laipuna & 11 & $5(45 \%)$ & $2(18 \%)$ & $3(27 \%)$ & 12.08 & 11.24 & 12.14 & $86-98 \%$ \\
\hline
\end{tabular}

pitfall collected material the number of shared species are five, with three exclusive to El Chilco and five exclusive to Laipuna. Of the 11 shared species, eight were collected both manually and with pitfall traps, and only three were collected manually. Six $(75 \%)$ of the shared species collected by both methods were found in at least five sample plots.

\section{Southern Ecuador Dry Forest Ants}

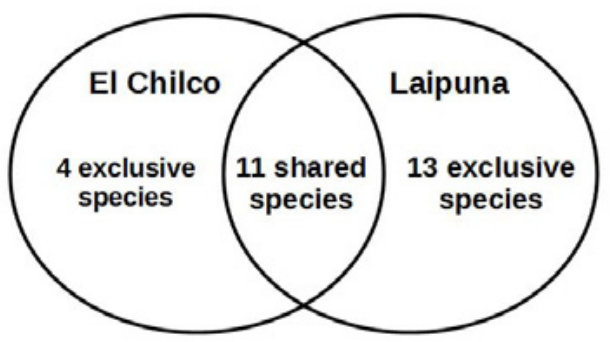

28 species total

Fig 1. Number of species collected for each subfamily at both sites.

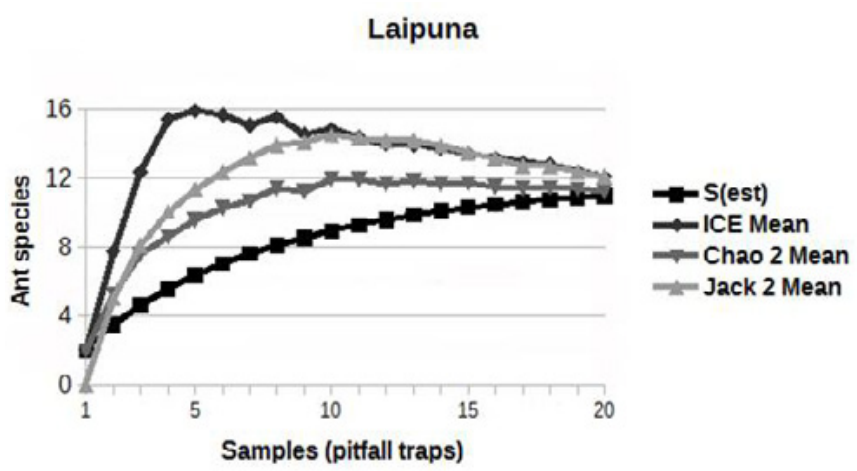

Fig 2. Species accumulation curve and estimator curves for the Laipuna Reserve dry forest.

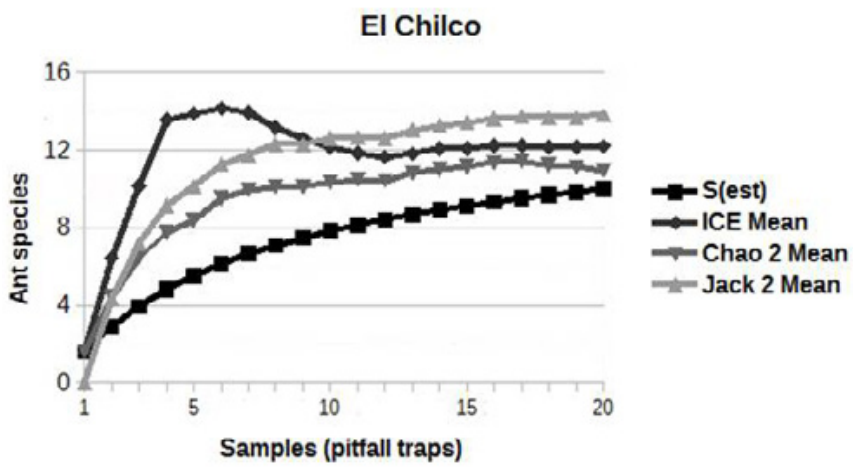

Fig 3. Species accumulation curve and estimator curves for the El Chilco dry forest.
Functional groups

The collected ants could be distributed amongst six functional groups (Table 4), with the most species rich FG being Generalist Epigeic Foragers with a total of 14 species, eight present in El Chilco, 12 present in Laipuna, with six shared species. The second most species rich FG is Arboreal Foragers with a total of seven species, of which three are present in El Chilco, four in Laipuna, with three shared species. Only two species of Generalist epigeic hunters were found, one in El Chilco and both present in Laipuna. A different species of Nomadic Hunter was found in each of the sites. The species of Rogeria Emery was not designated into any FG on account of the little information available on the biology of the genus (Kugler, 1994), especially for those species in arid environments.

\section{Selected species accounts}

Acromyrmex EC-02 (octospinosus complex). The amount of nocturnal Acromyrmex activity in Laipuna, especially close to the station, is impressive, with many active foraging columns from different colonies relatively near to one another, particularly in areas with greater tree cover. Many aggressive interactions were observed, with workers locked in combat, and a noticeable amount of dead and maimed workers piled throughout areas under greatest tree cover. In areas with sparse canopy the density seemed less and there were no noticeable "battlefields". In Fernández et al. (2015) the specimens key uneasily to $A$. octospinosus (Reich, 1793). The species at hand does not correspond to the image of a syntype (CASENT0900490) of A. octospinosus in Antweb (2016b) as its lateral propodeal spines are longer than the anterior mesonotal spines, and all are very elongate and slender The hairs issuing from the head, scapes, mesosoma, and gaster are all relatively longer than of the imaged type.

Camponotus atriceps (F. Smith, 1858), Camponotus conspicuus zonatus, and Camponotus EC-07 [cf. conspicuus zonatus] were not seen foraging during the day, in contrast

Table 3. Between site comparisons. 1 - number of species shared by 2 sites, 2 - Chao Jaccard similarity values, 3 - Chao Jaccard estimator values, 4 - dissimilarity or complementarity values.

\begin{tabular}{cccccc}
\hline $\begin{array}{c}\text { Transect } \\
\mathbf{1}\end{array}$ & $\begin{array}{c}\text { Transect } \\
\mathbf{2}\end{array}$ & $\begin{array}{c}\text { Shared } \\
\text { ssp }^{\mathbf{1}}\end{array}$ & $\begin{array}{c}\text { Chao } \\
\text { Jaccard }^{2}\end{array}$ & $\begin{array}{c}\text { Chao } \\
\text { Jace Est }^{3}\end{array}$ & Complement $^{4}$ \\
\hline Chilco & Laipuna & 11 & 0.657 & 0.694 & 0.63 \\
\hline
\end{tabular}


Table 4. Functional group diversity. 1- Total species for each group, 2- Species found only in each site, 3- Species shared amongst sites, 4percentage of shared species, 5- Functional group complementarity values between each site.

\begin{tabular}{lcccccc}
\hline \multicolumn{1}{c}{ Functional Groups } & Total species $^{\mathbf{1}}$ & Species Chilco $^{2}$ & Species Laipuna $^{2}$ & Shared species $^{\mathbf{3}}$ & \% Shared species $^{\mathbf{4}}$ & Cab $^{\mathbf{5}}$ \\
\hline Generalist epigeic hunters & 2 & 1 & 2 & 1 & $50 \%$ & 0.50 \\
Nomadic hunters & 2 & 1 & 1 & 0 & 0 & 1.00 \\
Fungus growing (detritus) & 1 & 0 & 1 & 0 & 0 & 1.00 \\
Fungus growing (fresh) & 1 & 1 & 1 & 1 & $100 \%$ & 0 \\
Epigeic omnivores & 14 & 8 & 12 & 6 & $43 \%$ & 0.57 \\
Arboreal foragers & 7 & 3 & 7 & 3 & $43 \%$ & 0.57 \\
\hline
\end{tabular}

with Camponotus EC-08. Camponotus conspicuus zonatus and $C$. EC-07 seem very closely related to each other on account of morphology. C. atriceps is widespread from Mexico into most of South America, found in many habitats from savannahs to forests but usually in disturbed areas. It can also be a domestic pest. This is the first record of $C$. conspicuus zonatus from the Ecuadorean mainland.

Cardiocondyla emeryi Forel, 1881 is non-native globally distributed tramp ant, recorded from the Galapagos (Herrera, 2014) but here recorded for the first time from mainland Ecuador. The same species has been reported in low densities in other dry forest sites in southern Ecuador such as Alamala, about $57 \mathrm{~km}$ NE from Laipuna (D. Donoso, personal communication, September 1, 2015). This species seems to have become a naturalized and discrete member of the local fauna.

Cephalotes maculatus (F. Smith, 1876) is a widespread species found from southern Mexico to northern Argentina with two previous records from Ecuador, both from lowland humid forested areas in the eastern part of the country (De Andrade \& Baroni Urbani, 1999; Ryder et al., 2010). A striking contrast in vegetation and climate with the present record suggesting considerable ecological flexibility.

Dorymyrmex pyramicus peruvianus Wheeler, 1919. This species was described from the Peruvian province of Piura, bordering with Ecuador. The specimens at hand match well with images of a Cotype in the USNM. The genus is reported as present in the country in Antwiki (2016b), but not in Antmaps (2016). We could not find a published record and neither could Salazar et al. (2015).

Ectatomma ruidum (Roger, 1860) is very flexible habitatwise, found not only in arid localities but also mesic forested areas, both disturbed and undisturbed, as well as urban parks and gardens throughout much of northern South America. Recent work by Nettel et al. (2015) strongly suggest what is presently known as E. ruidum includes more than one species. There is data to suggest the Laipuna E. ruidum may not be a single species (Domínguez et al. 2016). Nocturnal trail walking permitted observing abundant individuals of $E$. ruidum foraging in Laipuna, yet two pitfalls contained this species compared with 7 pitfalls, in each site, containing Odontomachus bauri Emery, 1892. In the field E. ruidum seems to have much slower movements than $O$. bauri, pausing intermittently or at the slightest disturbance, and this could partially explain the paucity of pitfall records for E. ruidum compared with O. bauri. E. ruidum was observed foraging after 16:30 $\mathrm{h}$.

Labidus coecus (Latreille, 1802). Cephalic capsules of Labidus coecus majors were found entangled in spider webs under rocks, and a single male was captured at a light one night. This is an extremely flexible, mostly subterranean ant, in its habitat preferences, ranging from lowland rainforests to paramo conditions at 3,000 $\mathrm{m}$ and geographically spread from southern Texas to northern Argentina (Wetterer \& Gordon, 2015).

Odontomachus bauri Emery is found throughout many types of habitats, from arid localities but also mesic forested areas, both disturbed and undisturbed, as well as urban parks and gardens at least throughout much of Colombia and Venezuela (Fernández, 2008). Its foraging activities were observed starting at approximately 18:30 h.

Pheidole EC-29, EC-30, and EC-31 all apparently belong to the diligens group. They are morphologically very similar and presumably quite closely related to each other, at least much more so than with Pheidole EC-32 or EC-33.

Pseudomyrmex kuenckeli (Emery, 1890) is widespread, though not necessarily common, in dry forests from Mexico to Paraguay and Argentina (Ward, 1999). In Laipuna these ants were found nesting in a Legume, apparently a species of Tachigali Aublet, though they generally do not nest in trees of this genus as they are associated with other members of the viduus group of Pseudomyrmex (Ward, 1999). They reacted very aggressively to our collecting efforts, forcing us to retreat from the vicinity of the trees. This is the first record of this species in Ecuador.

Pseudomyrmex boopis (F. Smith, 1855) is widespread from Mexico throughout northwestern South American, but little is known of its biology other than a preference for nesting in the ground in relatively mesic forests, so its presence in this dry forest underscores our scant knowledge about its biology. This is the second record of this species in Ecuador, the first being specimens studied by Kempf (1960) from near Río Bamba.

Rogeria EC-06. The two captured specimens were compared with other specimens of the same genus from the UTPL collection, images from Antweb (2016c), and examined using the revision by (Kugler, 1994) and the review by (Lapolla \& Sosa-Calvo, 2006). They do not seem to coincide with any of the known species. 
Tapinoma melanocephalum (Fabricius, 1793) is another non-native tramp ant. It was found in the kitchen of the station house only. Given this species is also known from other mainland localities in Ecuador (Donoso et al., 2014), it could be present in irrigated agricultural fields close to the station or habitats along the neighboring Catamayo River. It has been recorded in dry forest habitats further south in Lambayeque, Peru (Castro Delgado et al., 2008). Its absence in the sampling sites suggest the prevailing environmental conditions on the slopes are too extreme for its survival.

The cacti, and some other plants, in Laipuna had significant colonies of scale insects and these were frequented by ants, especially Crematogaster, and both species of Azteca.

\section{Discussion}

The accumulation curves and estimators suggest the ground fauna was relatively well sampled (72-98\%), especially in Laipuna, where the estimators converge close to the observed value. The situation is different for Zapotillo, with the curves spread apart and only the value of Chao2 approaching that of the observed value. Sampling in Zapotillo could be considered more intense as both litter samples and pit fall traps were used compared with Laipuna where only pitfalls were used. The increase in species richness may thus be in part due to the different methods used as Winkler and Pitfall traps are considered complementary, the larger ants with longer legs being taken more often with pitfall traps (Donoso \& Ramon, 2009).

Comparing species diversity in our sites with those of dry forest in southwestern Colombia we find the number of genera and species for southern Ecuador much lower. (ArcilaCardona et al., 2004) sampled poneromorph ants from five sites and found 22 species from 10 genera. A rarefaction curve puts species richness from just 20 of his samples at approximately eight "poneromorphs" from forest fragments alone, compared with only two for both sites of the present study. (Armbrecht \& Ulloa-Chacon, 1999) found a total of 38-81 species of ants each in seven different secondary forest fragments. The sampled Colombian dry forests have at least twice the annual rainfall as the Ecuadorean sites. The number of species for El Chilco and Laipuna have values similiar to those in more arid, desert like conditions such as scrub forests. Surveys of ants in arid environments of the Venezuelan coast yielded more similar species richness such as 22 and 31 species respectively for two sites on the Paria Peninsula (Pérez-Sánchez et al., 2013) and 30 - 42 species for three sites on the Paraguana Peninsula (Pérez-Sánchez et al., 2012). The Venezuelan sites averaged lesser annual precipitation than the Ecuadorean sites, ranging from 410 $244 \mathrm{~mm}$. (Castro et al., 2008) sampled ants manually and with pitfalls in the dry Ferreñafe region of Lambayeque in Peru, finding 21 morphospecies in four sites between 600 and 810 $\mathrm{m}$ above sea level.
Despite the very arid conditions both of the present sites have some tree cover, particularly El Chilco with trees over $20 \mathrm{~m}$ high, in contrast with the Venezuelan sites. The greater diversity of ants present in Laipuna vs. El Chilco, despite the greater rainfall and presence of leaf litter for the latter site, was unexpected. The presence of foraging goats in El Chilco as opposed to their abscence in Laipuna might have an influence, as their disruptive effects on understorey vegetation might reduce resources for ants that forage on the ground and low herbacious vegetation. Another underlying factor may be the slightly higher relative humidity and lower average temperature for Laipuna, conditions more amenable to ants than those in El Chilco. Precipitation is also slightly more concentrated in El Chilco with $98 \%$ falling from January to April while in Laipuna $85 \%$ of the precipitation is concentrated from January to March. The two sites share approximately a little under one half of their species, especially evident for the two most speciose functional groups, epigeic omnivores and arboreal foragers, implying that an important number of species are restricted to each site.

\section{Conclusions}

The number of new records, either for Ecuador or the Ecuadorean mainland, including the first published record for a relatively common and widespread genus such as Dorymyrmex, highlight the poor knowledge of the Tumbesian forest biota. We hope to point attention to this fact with the present evidence and encourage further surveys and other research on the ant fauna of this vast region of dry forests. The Tumbesian dry forests are not homogenous but quite varied and more extensive collecting, taking into account both seasonal and successional changes are sure to reveal further new records, probable new species, and a better resolution of how ants are distributed in this region.

\section{Acknowledgements}

We acknowledge to David Donoso, Cristina Gómez, María Tuza, Gabriela Piedra, William MacKay, Benoit Guénard, and José Ramirez for their assistance. M. Vélez carried out his share of the work as part of the requirements for obtaining the degree of Ingeniero Ambiental from the Universidad Nacional de Loja. D. Donoso for making valuable suggestions to the manuscript. Naturaleza y Conservación Internacional granted permission to carry out field work in the Laipuna Reserve. Mayron Escárraga helped with the mansucript. This research was mostly financed by the Prometeo Project of the Secretary for Higher Education, Science, Technology, and Innovation (SENESCYT) of the Republic of Ecuador. Additional support was provided by the Program for Biodiversity, Forests, and Ecosystem Services of the Universidad Nacional de Loja. 


\section{References}

Aguirre-Mendoza, Z. \& Kvist, L.P. (2005). Floristic composition and conservation status of the dry forests in Ecuador. Lyonia, 8: 41-67.

Ambuludí Macias, L.S. \& Aguirre-Mendoza, Z. (2009). Estudio comparativo de la composición florística, estructural y dinámica de la regeneración natural en bosque seco intervenido y no intervenido de la Reserva Laipuna, Macará, Loja.[Unpublished Undergraduate Thesis]. Loja: Universidad Nacional de Loja. 119pp.

Andersen, A.N. (2010). Box 8.2 Functional groups in ant community ecology. In: L. Lach, C.L. Parr and K. Abbott (eds) (pp. 142-144). Ant Ecology. Oxford: Oxford University Press.

Antmaps. (2016). http://antmaps.org/?mode=diversity\&genus =Dorymyrmex. (Accessed 10 August, 2016).

AntWeb. (2016a). Available from https://www.antweb.org. (Accessed 10 August, 2016).

AntWeb. (2016b). Available from: https://www.antweb.org/ specimenImages.do? name $=$ casent $0900490 \&$ countryName $=$ Cuba. Accessed 10 August, 2016.

AntWeb. (2016c). Available from: https://www.antweb.org/ images.do? name $=$ rogeria\&rank=genus\&Nearctic. (Accessed 10 August, 2016).

AntWiki. (2016a). http://www.antwiki.org/wiki/World_Ant_ Taxonomists. (Accessed 10 August, 2016).

AntWiki.(2016b).http://www.antwiki.org/wiki/Dorymy rmex \#Distribution. (Accessed 10 August, 2016).

Arcila-Cardona, A., Osorio, A.M., Bermúdez, C. \& Chacón de Ulloa, P. (2004). Diversidad de hormigas cazadoras asociadas a los elementos del paisaje del bosque seco. In: E. Jiménez, F. Fernández, T. Arias-Penna and F. Lozano-Zambrano (eds.). Sistemática, biogeografía y conservación de las hormigas cazadoras de Colombia (pp. 531-552). Bogota: Instituto de Investigación de Recursos Biológicos Alexander von Humboldt.

Armbrecht, I. \& Ulloa-Chacon, P. (1999). Rareza y diversidad de hormigas en fragmentos de bosque seco colombianos y sus matrices. Biotropica, 31: 646-53.

Bendix, J., Beck, E., Bräuning, A., Makeschin, F., Mosandl, R., Scheu, S. \& Wilcke, W. (2013). Ecosystem services, biodiversity and environmental change in a tropical mountain ecosystem of South Ecuador. Ecological Studies Vol. 221. Heidelberg: Springer Verlag. 440 pp. doi: 10.1007/978-3642-38137-9.

Bendix, J., Breuer, L., Farwig, N., \& Homeier, J. (2014). Joint core plot design. MRp|SE Newsletter: Monitoring and Research Platform South Ecuador, 1: 7-8. doi: 10.5678/lcrs/ pak823-825.cit.1260.
Bestelmeyer, B.T., Agosti, D., Alonso, L.E., Bandão, Brown, Jr., C.R.F., Delabie, J.H.C. \& Silvestre, R. (2000). Field techniques for the study of ground-dwelling ants: An overview, description and evaluation. In: D. Agosti, J.D. Majer, L.E. Alonso and T.R. Schultz (eds.). Ants: standard methods for measuring and monitoring biodiversity (pp. 122-144). Washington, D.C: Smithsonian Institution Press.

Brehm, G., Homeier, J., Fiedler, K., Kottke, I., Illig, J., Nöske, N.M., Werner, F.A. \& Breckle, S.-W. (2008). Mountain rain forests in southern Ecuador as a hotspot of biodiversity Limited knowledge and diverging patterns. In: E. Beck, J. Bendix, I. Kottke, F. Makeschin and R. Mosandl (eds.). Gradients in a Tropical Mountain Ecosystem. Ecological Studies Vol. 198 (pp. 15-23). Berlin: Springer Verlag.

Castro Delgado, S., Vergara Cobian, C. \& Arellano Ugarte, C. (2008). Distribución de la riqueza, composición taxonómica y grupos fucionales de hormigas del suelo a lo largo de un gradiente altitudinal en el Refugio de Vida Silvestre Laquipampa, Labayeque-Perú. Ecología Aplicada, 7: 89-103.

Colwell, R. K. (2013). EstimateS: Statistical estimation of species richness and shared species from samples. Version 9. User's Guide and application published at: http://purl.oclc. org/estimates.

Colwell, R. \& Coddington, J. (1994). Estimating terrestrial biodiversity through extrapolation. Philosophical Transactions of the Royal Society of London: Series B, 345: 101-108

De Andrade, M. L. \& Baroni Urbani, C. (1999). Diversity and adaptation in the ant genus Cephalotes, past and present. Stuttgarter Beit. Naturkunde, Ser. B, 271:1-889.

Thibaut, D., Sonet, G., Nagy, Z.T., Wauters, N., Jacquemin, J. \& Leponce, M. (2012). High species turnover of the ant genus Solenopsis (Hymenoptera: Formicidae) along an altitudinal gradient in the ecuadorian Andes, indicated by a combined DNA sequencing and morphological approach. Invertebrate Systematics, 26: 457-69. doi: 10.1071/IS12030.

Del Toro, I., Ribbons, R.R. \& Pelini, S.L. (2012). The little things that run the world revisited: A review of antmediated ecosystem services and disservices (Hymenoptera: Formicidae). Myrmecological News, 17: 133-46.

Domínguez, D., Marín-Armijos, D. \& Ruíz, C. (2015). Structure of dung beetle communities in an altitudinal gradient of Neotropical dry forest. Neotropical Entomology, 44: 40-46 doi: 10.1007/s13744-014-0261-6.

Domínguez, D., Bustamante, M., Albuja, R., Castro, A., Lattke, J.E., \& Donoso, D.A. (2016). Códigos de barras (COI barcodes) para hormigas (Hymenoptera: Formicidae) de los bosques secos del sur del Ecuador. Ecosistemas (in press)

Donoso, D.A., Onore, G., Ramón, G. \& Lattke, J.E. (2014). Invasive ants of continental Ecuador, a first account. Revista Ecuatoriana de Medicina y Ciencias Biológicas, 35: 133-41. 
Donoso, D.A. \& Ramón, G. (2009). Composition of a high diversity leaf litter ant community (Hymenoptera: Formicidae) from an Ecuadorian pre-montane rainforest. Annales de la Société Entomologique de France (n. s.), 45(4): 487-499.

Fernández, F. (2008). Subfamilia Ponerinae s. str. In E. Jiménez, F. Fernández, T.M. Arias and F.H. Lozano-Zambrano (eds.), Sistemática, biogeografía y conservación de las hormigas cazadoras de Colombia (pp. 124-218). Bogota: Instituto de Investigación de Recursos Biológicos Alexander von Humboldt.

Fernández, F., Castro-Huertas, V. \& Serna, F. (2015). Hormigas cortadoras de hojas de Colombia: Acromyrmex \& Atta (Hymenoptera: Formicidae). Fauna de Colombia. Monografía No. 5. Bogotá: Universidad Nacional de Colombia, $352 \mathrm{pp}$.

Folgarait, P. (1998). Ant biodiversity and its relationship to ecosystem functioning: a review. Biodiversity and Conservation, 7: 1221-1244.

Gradstein, S.R., Homeier, J. \& Gansert, D. (2008). The tropical mountain forest. Patterns and processes in a biodiversity hotspot. Biodiversity and Ecology Series Vol. 2, Göttingen Centre for Biodiversity and Ecology. Göttingen: Universitätsverlag Göttingen, 217 pp.

Guayasamin, J.M \& Bonaccorso, E. (2011). Evaluación ecológica rápida de la biodiversidad de los tepuyes de la Cuenca Alta del Río Nangaritza, Cordillera del Cóndor, Ecuador. In Guayasamin, J.M. \& Bonaccorso, E. (Eds.). RAP Boletín de Evaluación Ecológica Rápida 58. Quito: Conservation International, $135 \mathrm{pp}$.

Guenard, B. (2013). An overview of the species and ecological diversity of ants. In eLS, John Wiley \& Sons, Ltd., Chichester, 1-10. doi: 10.1002/9780470015902.a0023598.

Guénard, B. \& Lucky, A. (2011). Shuffling leaf litter samples produces more accurate and precise snapshots of terrestrial arthropod community composition. Environmental Entomology, 40: 1523-29. doi: 10.1603/EN11104.

Guerrero, R.J. \& Sarmiento, C. (2010). Distribución altitudinal de hormigas (Hymenoptera, Formicidae) en la vertiente noroccidental de la Sierra Nevada de Santa Marta (Colombia). Acta Zoologica Mexicana, 26: 279-302.

Herrera, H.W. (2014). CDF Checklist of Galapagos Ants. In Bungartz, F., H. Herrera, P. Jaramillo, N. Tirado, G. JiménezUzcátegui, D. Ruiz, A. Guézou and F. Ziemmeck. (eds.). Charles Darwin Foundation Galapagos Species Checklist. Charles Darwin Foundation, Puerto Ayora, Galapagos: http:// www.darwinfoundation.org/datazone/checklists/terrestrialinvertebrates/formicidae/, 28 January 2014.

INAMHI (2000-2010). Instituto Nacional de Meteorología e Hidrología. Anuarios Meteorológicos 2000-2010. Accessed at http://186.42.174.231/index.php/clima/anuarios-meteorologicos, 20 October 2014.
Kempf, W. W. (1960). Estudo sôbre Pseudomyrmex I. (Hymenoptera: Formicidae). Revista Brasileira de Entomologia, 9: 5-32.

Kugler, C. (1994). Revision of the ant genus Rogeria (Hymenoptera: Formicidae) with descriptions of the sting apparatus. Journal of Hymenoptera Research, 3: 17-89.

Lapolla, J.S. \& Sosa-Calvo, J. (2006). Review of the Ant Genus Rogeria in Guyana. Zootaxa, 68: 59-68.

Linares-Palomino, R. (2006). Phytogeography and floristics of seasonally dry tropical forests in Peru. In R.T. Pennington, J.A. Ratter and G.P. Lewis (eds.), Neotropical savannas and seasonally dry forests: plant biodiversity, biogeography and conservation (pp. 257-279). Boca Raton: CRC Press.

Loaiza, S. \& Christian, R. (2013). The Tumbesian Region of endemism: Biogeography, Diversity and Conservation. Biogeography, 6: 4-10.

Majer, J., Orabi, G. \& Besivac, L. (2007). Ants pass the bioindicator scorecard. Myrmecological News, 10: 69-76.

Muñoz, J., Erazo, S. \& Armijos, D. (2014). Composición florística y estructura del bosque seco de la quinta experimental "El Chilco" en el suroccidente del Ecuador. Cedamaz, 4 (1): 53-61.

Nettel-Hernanz, A., Lachaud, J.-P., Fresneau, D., LópezMuñoz, R.A. \& Poteaux, C. (2015). Biogeography, cryptic diversity, and queen dimorphism evolution of the Neotropical ant genus Ectatomma Smith, 1958 (Formicidae: Ectatomminae). Organisms, Diversity and Evolution, 15: 543-553. doi: 10.1007/s13127-015-0215-9.

Pérez-Sánchez, A.J., Lattke, J.E. \& Viloria, A. (2012). Composición y estructura de la fauna de hormigas en tres formaciones de vegetación semiárida de la península de Paraguaná, Venezuela. Interciencia, 37: 506-14.

Pérez-Sánchez, A.J., Lattke, J.E. \& Viloria, A. (2013). Patterns of ant (Hymenoptera: Formicidae) richness and relative abundance along an aridity gradient in Western Venezuela. Neotropical Entomology, 42, 128-136. doi: 10.1007/s13744-012-0096-y.

Peters, T. \& Richter M. (2011). Climate station data Reserva Laipuna Valley. DFG-FOR816dw. Accessed at http://www. tropicalmountainforest.org/data_pre.do?citid=964, 01 May 2015.

Philpott, S. \& Armbrecht, I. (2006). Biodiversity in tropical agroforests and the ecological role of ants and ant diversity in predatory function. Ecological Entomology, 31: 369-377.

Ribas, C.R., Campos, R.B.F., Schmidt, F.A. \& Solar, R.R.C. (2012). Ants as indicators in Brazil : a review with suggestions to improve the use of ants in environmental monitoring programs. Psyche (Stuttg), 1-23. doi: 10.1155/2012/636749.

Ryder Wilkie, K.T., Mertl, A.L. \& Traniello, J.FA. (2010). Species diversity and distribution patterns of the ants of amazonian Ecuador. PloS One 5. doi:10.1371/journal.pone.0013146. 
Salazar, F., Reyes-Bueno, F., Sanmartin, D. \& Donoso, D.A. (2015). Mapping continental ecuadorian ant species. Sociobiology, 62: 132-162.

Särkinen, T., Iganci, J.R.V., Linares-Palomino, R., Simon, M.F. \& Prado, D.E. (2011). Forgotten forests-issues and prospects in biome mapping using seasonally dry tropical forests as a case study. BMC Ecology, 11:27. doi: 10.1186/14726785-11-27.

Sierra, R., Cerón, C., Palacios, W. \& Valencia, R. (1999). Propuesta preliminar de un sistema de clasificación de vegetación para el Ecuador continental (194 pp). Quito: Proyecto INEFAN / GEF-BIRF y Eco-Ciencia.

Silvestre, R., Brandão, C.R.F. \& da Silva, R.R. (2003). Grupos funcionales de hormigas: el caso de los gremios del cerrado.
In F. Fernández (ed.), Introducción a las hormigas de la región neotropical (pp. 113-148). Bogotá: Instituto de Investigación de Recursos Biológicos Alexander von Humboldt.

Underwood, E. \& Fisher, B.L. (2006). The role of ants in conservation monitoring: If, when, and how. Biological Conservation, 132: 166-182.

Ward, P.S. (1999). Systematics, biogeography and host plant associations of the Pseudomyrmex viduus Group (Hymenoptera : Formicidae), Triplaris and Tachigali inhabiting ants. Zoological Journal of the Linnean Society of London, 126: 451-540.

Wetterer, J.K.\& Snelling, G.C.(2015). Geographic distribution of Labidus coecus (Latr.) (Hymenoptera, Formicidae), a subterranean army ant. Journal of Hymenoptera Research, 44: 31-38. doi: 10.3897/JHR.44.4672

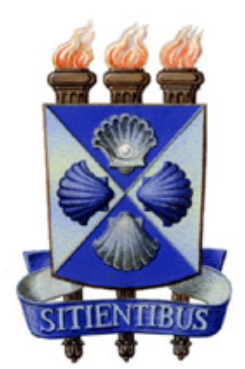

